\title{
Manajemen Pembelajaran Kitab Kuning Pola 100 Jam Menggunakan Metode Tamyiz
}

\author{
Farhan \\ UIN Sunan Gunung Djati Bandung, Indonesia \\ Email: farhanzz@gmail.com
}

\begin{abstract}
Learning yellow books is considered difficult by the students at Islamic boarding schools. There is a phenomenon, the Tamyiz method is effective for overcoming the difficulty of reading the yellow book. This shows that the Tamyiz method is a strategic key for students to be able to directly read, describe the word structure and translate the yellow book. The study aims to describe the planning of learning the 100-hour yellow book patterns using the Tamyiz method, organizing the learning of the 100-hour yellow book patterns using the Tamyiz method, the assessment of the 100-hour yellow book learning patterns using the Tamyiz method, the concept of the 100-hour yellow book learning model using the Tamyiz method. This research is a qualitative research using descriptive method, because this research describes comprehensively, holistically, and integratively. The results showed that the planning of the 100-hour yellow book learning pattern using the Tamyiz method determined the learning objectives, the steps used and the teaching materials developed were already good, organizing the learning of the 100-hour yellow book pattern was based on the principle of teaching fun and active learning so that learning outcomes more optimal. However, several aspects need more attention, the assessment of the learning of the yellow book pattern of 100 hours, the students are the main assessment objects. Assessment using the learning ability assessment instrument (Pre Test and Post Test), learning motivation, learning habits, attention to learning, and formative and summative assessment are all good, the concept of a 100 hour yellow book learning model integrates learning with the theories of educational experts so that learning planning organizing learning, and evaluating learning effectively and efficiently.
\end{abstract}

Keywords: Management, Yellow Book, Tamyiz

\begin{abstract}
ABSTRAK
Pembelajaran kitab kuning dianggap sulit oleh para santri di pondok pesantren. Terdapat fenomena, metode Tamyiz efektif untuk mengatasi kesulitan membaca kitab kuning. Hal tersebut menunjukkan bahwa metode Tamyiz menjadi kunci strategis bagi santri agar bisa langsung membaca, menguraikan struktur kata sekaligus menerjemahkan kitab kuning. Penelitian bertujuan untuk menggambarkan perencanaan pembelajaran kitab kuning pola 100 jam menggunakan metode Tamyiz, pengorganisasian pembelajaran kitab kuning pola 100 jam menggunakan metode Tamyiz,penilaian pembelajaran kitab kuning pola 100 jam menggunakan metode Tamyiz, konsep model pembelajaran kitab kuning pola 100 jam menggunakan metode Tamyiz. Penelitian ini merupakan penelitian kualitatif dengan menggunakan metode deskriptif, karena penelitian ini mendeskripsikan secara komprehensif, holistic, dan integratif secara mendalam. Hasil penelitian menunjukkan bahwa perencanaan pembelajaran kitab kuning pola 100 jam menggunakan metode Tamyiz menentukan tujuan pembelajaran, langkah-langkah yang digunakan, dan bahan ajar yang dikembangkan sudah baik, pengorganisasian pembelajaran kitab kuning pola 100 jam dilandasi dengan prinsip mengajar fun and active teching sehingga hasil pembelajaran lebih optimal. Namun, beberapa aspek perlu lebih diperhatikan, penilaian pembelajaran kitab kuning pola 100 jam, santri merupakan objek penilaian utama. Penilaian menggunakan instrument penilaian kemampuan belajar (Pre Test dan Post Test), motivasi belajar, kebiasaan belajar, perhatian belajar, dan penilaian formatif dan sumatif seluruhnya sudah baik, konsep model pembelajaran kitab kuning pola 100 jam mengintegrasikan pembelajaran dengan teori para ahli pendidikan sehingga perencanaan pembelajaran, pengorganisasian pembelajaran, dan penilaian pembelajaran secara efektif dan efisien.
\end{abstract}

Kata Kunci : Manajemen, Kitab Kuning, Tamyiz

* Farhan

Received: November 01, 2019; Revised: November 01, 2019; Accepted: Desember 30, 2019 


\section{PENDAHULUAN}

Perkembangan ilmu dan tekhnologi semakin mendorong derasnya arus globalisasi yang berdampak negatif maupun positif terhadap berbagai aspek kehidupan. Derasnya arus globalisasi sebagai contoh dapat kita lihat dengan bermunculannya beberapa produk tekhnologi terbaru dan beberapa inovasi kemudahan dalam membantu kehidupan sehari-hari (Muhammad Alfan Alfian, 2019). Hal tersebut, memberikan pengaruh terhadap kehidupan manusia, yaitu pengaruh negative dan positif. Pertama, pengaruh negatif yang dipengaruhi oleh derasnya arus globalisasi adalah dapat memperlemah culture bangsa sehingga diperlukan menata dan membenahi kembali berbagai sikap sosial kemasyarakatan dan kenegaraan. Kedua, pengaruh positif derasnya arus globalisasi adalah mudahnya mengakses informasi melalui berbagai hal misalnya: televisi, internet, sosial media dan lain sebagainya. Dua pengaruh globalisasi tersebut bersinggungan dengan potensi belajar anak dan pendidikan dalam lingkup yang lebih general (Muchit, 2013).

Salah satu usaha yang ideal untuk menumbuhkembangkan potensi yang dimiliki oleh anak yaitu melalui pendidikan. Sebagaimana telah dijelaskan dalm Undang-undang Nomor 20 Tahun 2003 tentang Sistem Pendidikan Nasional pasal I:

"Pendidikan adalah usaha sadar dan terencana untuk mewujudkan suasana belajar dan proses pembelajaran agar peserta didik secara aktif mengembangkan potensi diri untuk memiliki kekuatan spiritual, keagamaan, pengendalian diri, kepribadian, kecerdasan, akhlak mulia serta keterampilan yang diperlukan dirinya, masyarakat, dan bangsa".

Undang-undang di atas merupakan keseluruhan komponen yang saling berkaitan dan terpadu yang diarahkan pada tujuan pendidikan nasional. Dalam sistem pendidikan nasional disebutkan beberapa komponen sistem pendidikan seperti peserta didik, pembiayaan, sarana dan prasarana, tenaga pendidikan dan kependidikan, kurikulum (Iryana, 2014). Komponen tersebut tidak dapat dipisahkan satu dengan lainnya, sebagai contoh pendidikan tidak dapat terlepas dengan sarana dan prasarana karena sarana dan prasarana merupakan equipment of teaching yang membantu pelaksanaan pembelajaran sehingga interaksi guru dan peserta didik berjalan dengan baik. Sejalan dengan paparan undang-undang di atas, menurut Engkoswara yang dikutip oleh Badrudin menjalaskan bahwa dengan adanya penyelenggaraan pendidikan diharapkan mampu memberikan kontribusi positif sehingga manusia menjadi cerdas, memiliki skill, sikap hidup yang baik, dan dapat bergaul di masyarakat (Badrudin, 2014). Seluruh paparan tersebut dimaksudkan untuk membantu menumbuhkembangkan potensi (kemampuan) peserta didik.

Keberlangsungan pendidikan pula memiliki tujuan yang membantu peserta didik dalam menemukan potensinya. Tujuan pendidikan yang telah dijelaskan dalam Undang-undang tentang Sistem Pendidikan Nasional Nomor 20 Tahun 2003 Bab II mengenai Dasar Fungsi dan Tujuan Pasal 3 dijelaskan bahwa tujuan pendidikan nasional adalah:

"Pendidikan nasional berfungsi mengembangkan kemampuan dan membentuk watak serta peradaban bangsa yang bermartabat dalam rangka mencerdaskan kehidupan bangsa, bertujuan untuk mengembangkan potensi peserta didik agar menjadi manusia yang beriman dan bertakwa kepada Tuhan Yang Maha Esa, berakhlak mulia, sehat, berilmu, cakap, kreatif, mandiri, dan menjadi warga Negara yng demokratis serta tanggungjawab".

Dewasa ini, Pendidikan merupakan sebuah kebutuhan manusia untuk mencapai derajat lebih mulia di dunia maupun di akhirat. Pendidikan merupakan usaha sadar manusia agar supaya menjadi lebih baik. Menurut Azyumardi Azra yang dikutip oleh Badrudin memaparkan bahwa selain mengembangkan potensi yang dimiliki peserta didik, pendidikan pula merupakan suatu proses penyiapan generasi untuk 
menjalankan kehidupan dan memenuhi tujuan hidup secara lebih efektif dan efisien. Melalui pendidikan diharapkan lahir generasi muda yang berkualitas, memiliki wawasan luas, berkepribadian, dan bertanggungjawab untuk kepentingan masa depan.

Pendidikan merupakan proses belajar mengajar yang dilakukan hampir di seluruh lembaga pendidikan formal maupun lembaga non-formal (Pesantren, Lembaga Kursus, dan lain sebagainya). Pelaksanaan proses pembelajaran tidak dapat terlepas oleh beberapa komponen pendidikan, seperti peserta didik, tenaga pendidik dan kependidikan, sarana dan prasarana, metode dan media dalam pelaksanaan pembelajaran. Dalam perspektif psikologi, proses belajar peserta didik dapat terlaksana dengan baik dengan mengacu beberapa karakteristik dan gaya belajar peserta didik. Gaya belajar menurut ahli, menjelaskan terbagi menjadi tiga kondisi belajar, yaitu: a) visual; b) audio visual; dan c) kinestetik. Ketiga kondisi tersebut dapat menggambarkan pola belajar yang efektif bagi peserta didik.

Charles J. Fornaciari Amy L. Kenworthy-U'Ren Florida Gulf Coast University Bond University dalam Artikelnya berjudul: $A$ "How-To" Issue of Service-Learning In Management Education menyatakan bahwa:

"Service-learning is a teaching tool that continues to receive a great deal of national and international attention. Over the past decade, service-learning programs, forums, and summits have taken place in countries including Argentina, Australia, Brazil, Canada, Germany, India, Ireland, Italy, South Africa, Spain, Taiwan, and Thailand. Such widespread interest not only occurs across nations but also across university courses. Service-learning has been successfully integrated into a wide spectrum of disciplines ranging from accounting to sociology Service learning".

Artinya adalah, keseluruhan dalam proses pembelajaran, yang harus diutamakan adalah pelayanan dalam pembelajaran. Penelitian di atas menyatakan bahwa pelayanan pembelajaran sangat berpengaruh dalam kedisiplinan dan telah disatupadukan dengan keilmuan sosial. Pelayanan pembelajaran telah diaplikasikan di beberapa negara.

Proses belajar dan pembelajaran adalah suatu aktifitas belajar-mengajar yang memiliki dua subjek yaitu pendidik dan peserta didik. Tugas dan tanggungjawab utama seorang pendidik adalah mengelola pembelajaran secara aktif, efektif, efisien, dinamis dan positif, yang ditandai dengan adanya kesadaran dan keterlibatan aktif diantara dua subjek pembelajaran. Pendidik sebagai master plan awal dan penginisiatif awal serta pembimbing, sedangkan peserta didik/ santri adalah sebagai yang mengalami dan keterlibatan aktif untuk memperoleh perubahan diri dalam pembelajaran. Untuk memiliki hasil pembelajaran yang maksimal, maka diperlukan juga strategi dan pola pembelajaran yang membantu peserta didik/ siswa/ Santri mencapai tujuan pembelajaran yang efektif, aktif dan efisien menggunakan beberapa penelitian dari gaya belajar peserta didik/ santri.

Standar Proses yang dijelaskan dalam Permendiknas No. 41 tahun 2007, bahwa proses pembelajaran yang ideal dalam kelas adalah maksimum berjumlah 32 orang dengan mencakup beberapa aspek, yaitu adanya perencanaan proses pembelajaran, pelaksanaan proses pembelajaran, penilaian hasil pembelajaran, dan pengawasan proses pembelajaran. Aspek perencanaan melingkupi Silabus dan Rencana Pelaksanaan pembelajaran. Kedua, Aspek pelaksanaan melingkupi persyaratan proses pembelajaran, buku teks pembelajaran, dan pengelolaan kelas. Ketiga, Aspek Penilaian hasil belajar dilakukan oleh guru untuk mengukur tingkat pencapaian kompetensi peserta didik, bahan penyusunan laporan kemajuan hasil belajar, dan memperbaiki proses pembelajaran. Keempat, Aspek pengawasan pembelajaran melingkupi pemantauan, supervisi, evaluasi, pelaporan dan tindak lanjut. Keberlangsungan empat aspek di atas, menunjukan bahwa proses pembelajaran harus menyiapkan perencanaan, pelaksanaan dan pengawasan agar tujuan pembelajaran tercapai secara efektif dan efisien menggunakan pola pengajaran dan metode yang menarik. 
Kesuksesan dan pencapaian tujuan pembelajaran dapat dievaluasi hasil pembelajaran. Menurut Muhibbin menjelaskan beberapa evaluasi hasil pembelajaran menggunakan dimensi cipta, ranah rasa, maupun ranah karsa yaitu menghasilkan tiga unsur teori hasil belajar peserta didik, yaitu evaluasi hasil kognitif, evaluasi hasil pembelajaran afektif, dan hasil pembelajaran psikomotor (Yaumi, 2013). Ketiga unsur tersebut, dapat membantu pendidik maupun peserta didik/ santri dalam mengenali kemampuan daya nalar dan prestasi belajar mereka (Badrudin, 2014).

Pada umumnya, proses pembelajaran yang dilakukan oleh lembaga formal dan non formal membutuhkan proses pembelajaran yang panjang agar hasil pembelajaran juga lebih maksimal. Dalam penelitian ini, penulis mencontohkan proses pembelajaran yang dilakukan di lembaga pendidikan non formal (pondok pesantren) menggunakan proses pembelajaran yang konstan agar peserta didik/ santri dapat memahami, membaca kitab kuning dan menerjemahkan Quran. Pada kadar ilmiahnya, santri selalu mendapatkan pengajaran dalam kitab kuning setidaknya mampu menguasai ketempilan menulis, mendengar dan mengucapkan bahasa Arab. Namun realita yang terjadi berbanding terbalik dengan teori bahwa pendidikan dan pembelajaran harus melihat aspek-aspek psikologis dan gaya belajar santri agar proses pembelajaran dapat dilaksanakan secara komprehensif dan maksimal.

Salah satu ciri khusus membedakan lembaga pendidikan formal dan pendidikan pondok pesantren adalah adanya pengajaran kitab-kitab agama klasik berbahasa Arab, atau yang lebih popular disebut dengan Kitab Kuning. Meskipun fenomena saat ini pondok pesantren melakukan banyak pembaharuan yaitu dengan memasukkan pengajaran pengetahuan umum sebagai suatu bagian penting dalam pendidikan pesantren, namun pengajaran kitab-kitab kuning terutama karangan ulama yang mengikuti karangan Syafi'iyah tetap diberikan di pesantren sebagai usaha untuk meneruskan tujuan utama pesantren. Tujuan pesantren adalah membentuk kepribadian, memantapkan akhlak dan melengkapinya dengan pengetahuan (Qomar, 2013).

Sebagai lembaga dakwah islamiyah, pesantren berusaha mendekati masyarakat dengan mewujudkan pembangunan dan terlibat aktif dalam mobilisasi pembangunan sosial masyarakat (Rayana, 2019). Oleh karena itu, pesantren menurut Ma'shum menjelaskan bahwa fungsi pesantren terdapat tiga aspek, yaitu: religious (diniyyah), fungsi sosial (ijtimaiyah), dan fungsi edukasi (tarbawiyah). Dalam aspek pendidikan/ edukasi (tarbawiyah), pesantren memiliki referensi-referensi kitab rujukan dalam pembelajarannya.

Adapun perkembangan-perkembangan kitab yang digunakan oleh pesantren, para ahli sejarah mengalami banyak kesulitan dalam merekam seluruh jenis kitab rujukan pada masa paling awal pertumbuhannya. Saat ini, kitab kuning merupakan panduan utama pembelajaran agama islam dalam dakwah islamiyah agar santri/ peserta didik yang ikut mengkaji dan mengaji kitab kuning dapat mengambil pelajaran dan dapat diaplikasikan ke dalam kehidupan sesungguhnya. Oleh sebab itu, pada seharusnya kitab kuning disikapi seperti pada kitab lainnya sebagai produk budaya yang harus dikembangkan dan dilestarikan.

Metode pembelajaran kitab kuning di pesantren klasik masih menggunakan metode pembelejaran tradisional, yaitu menggunakan metode bandongan dan sorogan. Metode sorogan merupakan suatu metode yang ditempuh dengan cara guru menyampaikan pelajaran kepada para santri secara individual, biasanya dilangsungkan di pesantren maupun di langgar, masjid atau terkadang malah di rumah-rumah (Qomar, 2013). Sedang wetonan atau bandongan adalah metode yang paling utama di lingkungan pesantren dengan cara guru membaca, menterjemahkan, menerangkan dan mengulas buku-buku Islam dalam bahasa Arab sedangkan sekelompok santri mendengarkan. Kedua metode pembelejaran tersebut dikatakan efektif pada masa itu. Namun, dengan berkembangnya zaman, maka metode pembelejaran 
dituntut untuk lebih efektif dan efisien untuk memberikan pemahaman dan pembelajaran yang baik kepada para santri.

Secara fenomena, pondok pesantren pada umumnya mengajarkan pembelajarannya dengan menggunakan metode klasikal (Mu'ammar, 2019) seperti bandongan dan sorogan, lain halnya dengan pembelajaran kitab kuning menggunakan metode tamyiz di pondok pesantren Bayt Tamyiz Tukdana Indramayu. Metode yang ditawarkan di pondok pesantren ini adalah metode yang mampu menghasilkan santri selain bisa baca Quran dan kitab kuning melainkan mentarjamah, menulis (imla) dan memahaminya. Selain waktu yang minim namun hasil pembelajaran yang maksimal, perbedaan lainnya yang mencolok juga dapat peneliti kemukakan bahwa dalam pembelajaran kitab kuning pola 100 jam menggunakan metode tamyiz ini tidak membatasi tingkatan minimal dan maksimal jenjang umur dan pendidikan yang mau belajar, maka pembelajaran akan dilaksanakan.

Pola dan metode pembelajaran di pondok pesantren tradisional menuntut santri agar dapat memahami dan mengerti kitab kuning yang mereka baca (Dhofier, 2015). Tidak banyak pula, santri yang sudah mengenyam pendidikan selama 4 tahun namun dia belum bisa membaca maupun memahami apa yang mereka baca (Komariah, 2014). Jika dalam rasio, sebanyak 10 orang yang telah belajar kitab kuning, namun hanya 3 orang di antara mereka yang mahir membaca dan memahami kitab kuning itu pula membutuhkan waktu yang lama dan tidak efisien.

Mengamati fakta-fakta yang terjadi di lapangan yang telah diuraikan di atas, telah mendorong peneliti untuk melakukan kajian lebih lanjut, agar permasalahan tersebut diperoleh jalan keluarnya, yang pada akhirnya dapat memberikan kontribusi terhadap usaha-usaha pencapaian tujuan pendidikan pada umumnya dan tujuan pembelajaran yang efektif dan efisien pada khususnya (Ujiyati, 2013). secara konsep dan fenomena yang ada, dalam mengajarkan santri/ peserta didik untuk dapat mahir membaca, menerjemahkan, dan memahami kitab kuning membutuhkan waktu yang cukup lama. Namun, dengan pola 100 jam dengan menggunakan metode Tamyiz, santri/ peserta didik mampu membaca, menerjemahkan, dan memahami kitab kuning. Dengan demikian perlu adanya upaya nyata dan kesungguhan penelitian tentang Manajemen Pembelajaran Pola 100 jam ini sehingga benar-benar berdampak positif bagi perkembangan potensi dan kemampuan belajar santri/ peserta didik sebagai kader masa depan bangsa (Silalahi, 2014).

\section{METODE PENELITIAN}

Dalam kaitan dengan penelitian di SD CLS sebagaimana disebutkan dalam pengertian penelitian, yakni pengumpulan data, tentunya peneliti harus mempertimbangkan karakteristik penelitian dalam pendidikan dimana penelitian tersebut harus memiliki karakteristik; obyektif, tepat, sah, dapat dijelaskan, empiris, logis, dan kondisional (Terry, 2014). Selanjutnya, dengan memperhatikan tujuan penelitian maka peneliti menggunakan pendekatan penelitian yang bersifat kualitatif dimana peneliti berupaya mengeksplorasi informasi, baik yang terdapat dalam penelitian, partisipan, dan lokasi penelitian secara interaktif serta menganalisis fenomena dan makna-makna (Cresswell John W, 2014). Agar fenomena yang terjadi di lokasi penelitian terungkap apa adanya (alamiah) maka penelitian ini pun bersifat fenomenologis (Buckley Philip dan Irawan, 2015). peneliti menggunaan pendekatan kualitatif. Metode/ pendekatan ini diambil dengan pertimbangan bahwa permasalahan yang ada di lapangan pada objek penelitian membutuhkan pengkajian yang detail dan mendalam, bukan sekedar melihat dan mengamati datat-data berupa angka-angka yang seringkali dimunculkan dan dijadikan bahan kajian dalam penelitian (Sugiyono, 2013). Sistematis artinya adalah proses yang digunakan dalam penelitian ini menggunakan langkah-langkah tertentu yang bersifat logis dan mudah 
difahami oleh nalar dan indera manusia. Pendekatan penelitian kualitatif seperti ini disebut dengan pendekatan kualitatif-fenomenologis (Al-Tabany, 2014). Pendekatan ini mengungkap fakta dan fenomena secara alamiah atau apa adanya. Pikiran dan persepsi peneliti sedemikian rupa direduksi agar data tersajikan secara wajar (Buckley Philip dan Irawan, 2015).

\section{HASIL DAN PEMBAHASAN}

Pondok pesantren melakukan perannya sebagai fungsi penyeimbang kebutuhan manusia agar supaya memiliki akhlakul karimah dan pengetahuan keagamaan yang baik, hal tersebut diharapkan dapat diterapkan dalam sistem pondok pesantren secara menyeluruh sehingga tercapai pula tujuan pendidikan pada umumnya yang bercita-cita menciptakan generasi yang bertakwa kepada Tuhan Yang Maha Esa, dan lain sebagainya.Maka, dalam penerapannya, pondok pesantren dibantu dengan fungsi-fungsi manajemen pada setiap kegiatan dan sistem yang direncanakan, dilakukan dan dievaluasi. Selain itu, dengan menggunakan fungsi manajemen tersebut diharapkan kegiatan pembelajaran keagamaan yang dilakukan pondok pesantren dapat terlaksana sesuai dengan yang diharapkan, praktis dan pragmatis (Irawan, 2019)

Beberapa hal yang dihasilkan peneliti dalam meneliti pembahasan manajemen pembelajaran kitab kuning pola 100 jam menggunakan metode tamyiz. Namun, pada pembahasan penelitian ini peneliti membatasi pembahasan sesuai dengan kebutuhan manajemen pembelajaran yang terjadi di lapangan, diantaranya adalah : perencanaan pembelajaran, pengorganisasian pembelajaran, penilaian pembelajaran, konsep model pembelajaran kitab kuning pola 100 jam menggunakan metode Tamyiz.

\section{Perencanaan Pembelajaran kitab kuning pola 100 jam menggunakan Metode Tamyiz di Pondok pesantren Bayt Tamyiz Tukdana Indramayu}

Metode pembelajaran Tamyiz secara umum dilaksanakan dengan manajerial yang baik. Salah satu hal yang dirasakan baik adalah perencanaan pembelajaran yang dilakukan adalah merencanakan pembelajaran menggunakan teori para ahli pendidikan.

Teori yang diaplikasikan dalam Tamyiz (cara mudah membaca Quran dan kitab kuning pola 100 jam) adalah teori Sobri Sutikno. Dalam karangannya, Sobri menjelaskan bahwa terdapat beberapa perencanaan yang digunakan dalam merencanakan pembelajaran, yaitu : tujuan pembelajaran, metode pembelajaran, bahan ajar, media pembelajaran dan lain sebagainya.

Perencanaan yang ditekankan dalam hal ini adalah pembuatan aransemen lagu dan pencocokan lirik dengan nada untuk pembelajaran. Dalam hal ini, Tamyiz merupakan sebuah metode yang mengedepankan cara mengajar (al-thariqoh) yang menyentuh pemahaman dari kalangan Sekolah Dasar (SD) sampai umum dengan menggunakan gerakan dan syair-syair lagu dalam menerapkan pemahaman gramatikal bahasa Arab.

Faktor yang mendukung perencanaan pembelajaran metode Tamyiz adalah santrinya sendiri. Santri merupakan hal pokok dalam pembelajaran karena santri merupakan obyek transformative pengetahuan yang diberikan pengajar kepadanya. Selain itu, pengajar juga merupakan komponen yang tidak kalah pentingnya dengan santri sebagai objek. Pengajar merupakan komponen subjek dalam pengajaran.

Perencanaan pembelajaran kitab kuning pola 100 jam yang dilaksanakan kepada guru dalam pembahasan ini, peneliti menitik beratkan dalam teamwork seluruh pengajar. Hal tersebut terlihat dalam mengevaluasi perencanaan pembelajaran yang dilaksanakan pada hari Senin dan Kamis. Kedua hari 
tersebut seluruh guru membahas hal-hal yang dirasakan oleh pengajar metode Tamyiz yang baru dan mengungkapkan kesan mereka selama mengajarkan tamyiz pada santri.

Pondok pesantren Bayt Tamyiz mengakui dalam hal perencanaan pembelajaran kitab kuning, ada beberapa hal yang menjadi titik kelemahan yaitu sumber daya manusia, sarana dan prasarana yang kurang lengkap dan manajemen pembiayaan.Kelemahan tersebut dapat menganggu keberlangsungan pembelajaran kitab kuning.Perencanaan merupakan rumusan terhadap penanganan atas kemungkinan timbulnya masalah-masalah yang akan dihadapi. Jika hal tersebut tidak diperhatikan, maka pola pembelajaran yang dilaksanakan akan menjadi kabur, tidak terarah dan tidak tercapainya sesuai tujuan yang telah direncanakan. Pada akhirnya, ketidak tercapaiannya peranan yang diharapkan, yaitu terwujudnya muslim yang pintar tarjemah Quran dan kitab kuning yang dibaca dan didengarnya.

Faktor penghambat dalam merencanakan pembelajaran menggunakan metode Tamyiz adalah kekakuan pengajar, sifat angkuh pengajar, dan kemalasan pada diri santri. Beberapa faktor penghambat tersebut satu persatu telah mendapatkan jalan keluar. Namun, jika santri malas dan semangatnya enurun, maka pengurus bagian Tata Usaha (Ustad Nasir) akan memberikan peringatan sebanyak tiga kali untuk memacu kembali semangat belajar santri. Selain itu orientasi pembelajaran terlampau idealis bukan empiris atau praktis atau pragmatis. Umumnya para pengajaran menghindari pembelajaran yang praktis karena dianggap rendah, kurang mengeksplorasi kemampuan berpikir santri. Padahal pembelajaran yang praktis senantiasa memberikan tempat kepada santri/siswa/murid/ untuk memecahkan masalah secara praktis bukan semata-mata ideologis (Irawan, 2019).

Perencanaan pembelajaran Tamyiz telah tersistem secara sistematis. Sistem pembelajaran selama 100 jam (setara dengan empat pekan) tersebut terbagi menjadi dua sistem pembelajaran dengan harapan santri selain mampu menguasai materi, santri juga dapat memberikan hasil pembelajaran kepada orang lain. Kedua sistem tersebut diantaranya terbagi menjadi dua waktu, yaitu :1) selama dua minggu, santri diberikan teori-teori tentang nahwu-shorof menggunakan syair-syair; 2) dua minggu berikutnya santri masuk ke dalam aplikatif kitab kuning yaitu mengaplikasikan teori ke dalam kitab gundul (tanpa shakal/ harakat).

Hal di atas dimaksudkan agar selain teori yang didapatkan, santri juga dapat mengaplikasikan teori tersebut ke dalam kitab kuning. Perencanaan tersebut dimaksudkan agar pada akhirnya santri dapat membaca, menerjemahkankan, menulis (imla) hingga memahami apa yang mereka dengar dan lihat serta pada akhirnya santri dapat membaca kitab kuning digital yang digunakan sebagai referensi keilmuan dan tambahan pengetahuan keagamaan mereka.

\section{Pengorganisasian Pembelajaran Kitab kuning pola 100 jam menggunakan metode Tamyiz di pondok pesantren Bayt Tamyiz Tukdana Indramayu}

Penerapan manajemen pembelajaran kitab kuning pola 100 jam menggunakan metode tamyiz salah satunya adalah pengorganisasian pembelajaran. Pembelajaran yang dilaksanakan merupakan kegiatan yang padat dan terencanakan sebelumnya. Jadi, pelaksanaan/ pengorganisasian pembelajaran kitab kuning pola 100 jam menggunakan metode Tamyiz merupakan hal yang terencana dan bukan bersifat insidental.

Pengorganisasian pembelajaran kitab kuning pola 100 jam (cara cepat menerjemahkan Quran dan kitab kuning) tersebut menggunakan riset dan buku (handbook) yang telah dirancang oleh abah dan seluruh tim pengajar serta bidang pendidikan dan pengajaran. Buku yang digunakan santri pada umumnya adalah buku yang akan mereka gunakan selama pembelajaran berlangsung. Buku pegangan santri dalam pembelajaran Tamyiz ini terdiri dari beberapa jilid. Pertama, Tamyiz 1. Buku Tamyiz satu di 
dalamnya adalah mengenal huruf. Kedua, buku handbook Tamyiz 2. Buku Tamyiz dua di dalamnya berisikan tentang syair-syair dan kaidah nahwu-shorof yang harus santri kuasai.

Pelakasanaan pembelajaran kitab kuning pola 100 jam menggunakan metode Tamyiz pada dasarnya adalah menjawab hal yang dianggap sulit oleh masyarakat. Salah satunya adalah santri atau masyarakat pada umumnya telah memformulasikan diri bahwa pembelajaran nahwu-shorof adalah salah satu sub keilmuan yang sulit untuk dipelajari. Jawaban yang tepat untuk permasalah tersebut adalah mereka harus belajar metode Tamyiz untuk menguasai sub keilmuan tersebut.

Pengorganisasian pembelajaran kitab kuning pola 100 jam tidak dianggap sebagai sebuah kekakuan, melainkan disesuaikan dengan kemampuan santri, kondisi belajar dan gaya belajarnya. Caracara yang dilakukan pengajar dalam mengajarkan metode Tamyiz dipandang efektif, sehingga santri secara bertahap memiliki kemampuan menerjemahkan Quran dan kitab kuning, membaca Quran dan kitab kuning, menulis (imla) Quran dan kitab kuning hingga cakap menggunakan kitab kuning digital seperti maktabah syamilah, kitab as-Sab'ah, dan lain sebagainya dan diharapkan kemampuankemampuan tersebut dapat dirasakan oleh seluruh santri yang belajar.

Pengorganisasian pembelajaran yang fun and active learning menjadikan metode Tamyiz sebagai metode yang cocok untuk seluruh kalangan, tingkatan pendidikan dan umur. fun and active learning merupakan prinsip pengajar memberikan bahan ajar kepada seluruh santri. Hal tersebut diformulasikan oleh tim pengajar sebagai penyampaian/ metode pembelajaran yang mudah diterima dan tidak memiliki unsur kekakuan, kasar dan jauh dari tindakan yang membuat santri enggan untuk bertanya.

Langkah manajemen pembelajaran selanjutnya menerapkan pembelajaran sesuai rencana yang telah dibuat. Dalam pengorganisasian pembelajaran kitab kuning pola 100 jam menggunakan metode Tamyiz di Pondok Pesantren Bayt Tamyiz Tukdana Indramayu memiliki beberapa tahapan pelaksanaannya, yaitu: Pertama, pengajar akan mengidentifikasi pendekatan apa yang sesuai dengan karakteristik santri. Kedua, pengajar akan mengidentifikasi aspek metode yang relevan dengan kebutuhan santri. Ketiga, adalah prosedur pembelajaran yang berisi: (1) kegiatan pendahuluan, melipti salam pembuka, pre test, absensi; (2) kegiatan inti, meliputi penyampaian materi, bahan ajar, penggunaan media (menggunakan gendang (alat musik dari kulit) untuk mengiringi syair-syair yang dinyanyikan selama pembelajaran berlangsung), metode pembelajaran (selain metode drill, diskusi, dan metode demonstrasi juga sering digunakan dalam pembelajaran agar santri mampu mengembangkan sendiri materi/ bahan ajar); (3) kegiatan akhir yaitu meliputi menyimpulkan pembelajaran, penilaian motivasi santri, kebiasaan belajar santri, kemampuan santri, melakukan post test, dan salam penutup.

Sistem moving class yang sekarang sedang gandrung dalam dunia pendidikan formal Indonesia, ternyata pesantren Tamyiz sudah melaksanakannya jauh-jauh sebelumnya. Sistem tersebut diterapkan agar santri yang belajar tidak mudah jenuh. Selain itu, media yang dalam pembelajaran Tamyiz menggunakan gendang (alat musik dari kulit) untuk mengiringi syair-syair yang dinyanyikan selama pembelajaran berlangsung. Hal tersebut agar supaya santri tidak merasa terbebani dan ter-sugesti jika belajar nahwu-shorof itu sulit serta membuat santri merasa nyaman dan menyenangkan dalam belajar.

Pesantren Tamyiz dalam pengorganisasian pembelajarannya menggunakan beberapa indikator ketercapaian pembelajaran. Indikator tersebut diantaranya adalah memiliki gedung, kurikulum, sarana dan fasilitas, pengajar, santridan dinamika kelas dalam belajar. Seluruh komponen pengorganisasian tersebut yang dirasakan oleh abah (pengasuh pesantren Bayt Tamyiz) sendiri adalah pengelolaan yang kurang ter-menej dengan baik dan benar.

Salah satu contohnya adalah penggunaan saran dan fasilitas santri. Abah mengakui bahwa pesantren Bayt Tamyiz dari segi sarana dan fasilitas sangatlah jauh dari pada kebutuhan. Namun dengan 
kekurangan tersebut, abah selalu mencoba dan terus berusaha agar pembelajaran kitab kuning (hasil riset abah) berjalan maksimal dan mampu menciptakan muslim yang mampu menjawab tantangan zaman ilmu kegamaan saat ini.

Pengajar pesantren Tamyiz dapat dikatakan masuk ke dalam kategori mumtaz. Kategori tersebut tentulah harus memenuhi beberapa kriteria penilaian seblum mereka menjadi staf pengajar. Kriteria yang harus dimiliki oleh calon pengajar metode tamyiz adalah telah menyelesaikan seluruh materi pembelajaran, kompetitif, jujur, inovatif, menyenangkan dan memiliki akhlak yang baik (akhlakul karimah). Jika seluruh kriteria pengajar tersebut dapat terpenuhi oleh calon pengajar, maka ia layak dan dianggap mampu mengajarkan metode tamyiz. Pelaksanaan pembelajaran selain menggunakan metode yang menyenangkan, Tamyiz juga menggunakan rumah warga sebagai kelas pembelajaran kitab kuning mereka.

Penggunaan rumah warga dilakukan karena keterbatasan pesantren menyediakan ruang kelas yang saat ini masih dalam tahap konstruksi. Namun hal tersebut tidak mematahkan semangat belajar dan transformasi pengetahuan. Sedangkan menurut peneliti hal tersbut dianggap positif karena pesantren mampu merangkul dan memberikan andil yang positif terhadap warga sekitar.

Beberapa program kegiatan pengorganisasian pembelajaran santri adalah shalat lima waktu berjamaah dan dzikir, pemanasan materi belajar, pembelajaran inti tamyiz (kelas Tamyiz), pembelajaran pendidikan formal, dan pengajian oleh abah. Seluruh kegiatan tersbut dilaksanakan dalam keseharian santri selama menempuh pembelajaran di pesantren Bayt Tamyiz.

Peneliti menjelaskan bahwa faktor pendukung santri belajar efektif metode tamyiz adalah guru yang kompeten, menyenangkan dan selalu mengadakan evaluasi selama pelaksanaan pembelajaran berlangsung. Pada faktanya, pembelajaran nahwu-shorof menggunakan metode Tamyiz ini dapat menyentuh kalangan santri kecil (SD/MI) dan mereka mampu menguasai, membaca dan menerjemahkankan kitab kuning dalam waktu yang singkat. Sedangkan faktor penghambat yang dirasakan oleh peneliti adalah rasa traumatic santri yang masih menganggap belajar nahwu-shorof adalah sub pelajaran gramatikal bahasa Ara yang sulit untuk dipahami.

\section{Penilaian Pembelajaran Kitab kuning Pola 100 Jam Menggunakan Metode Tamyiz di Pondok Pesantren bayt Tamyiz Tukdana Indramayu}

Penilaian merupakan fungsi akhir manajemen. Penilaian pembelajaran menurut beberapa ahli (yang telah di jelaskan di atas) adalah pemberian nilai proses untuk mengetahui kelebihan dan kelemahan pelaksanaan pelaksanaan sehingga dapat dituangkan sebagai perencanaan kembali.

Penilaian pembelajaran kitab kuning pola 100 jam menggunakan metode Tamyiz merupakan hal yang sangat kompleks dan membutuhkan beberapa pihak dalam penentuannya. Dalam pembahasan penilaian pembelajaran kitab kuning, terdapat beberapa hal yang menjadi sorotan penilaian, abah Zaun membaginya ke dalam Sembilan bahan pokok penilaian, diantaranya adalah kemampuan santri, minat belajar santri, perhatian belajar santri, motivasi belajar santri, kbiasaan santri, karakteristik santri, penilaian test dan non-Test, Pre-Test dan Post Test.

Penilaian yang disajikan pesantren sebagai suatu keberhasilan pesantren menerapkan dan melaksanakan pembelajaran kitab kuning pola 100 jam kepada santri adalah salah satu bukti keseriusan pesantren sehingga menciptakan generasi muslim yang mampu menerjemahkan Quran dan membaca kitab kuning.

Keberhasilan pesantren dan metode Tamyiz ini tidak boleh dianggap sebagai sebelah mata. Lulusan yang telah dihasilkan pesantren Bayt Tamyiz pada dasarnya memiliki rasa kepercayaan diri yang matang 
sehingga mereka mampu mendapatkan beberapa prestasi baik tingkat lokal, regional bahkan nasional. Salah satunya adalah mereka pernah mendapatkan juara 1 terbaik membaca kitab kuning di Kabupaten Indramayu. Hal tersebut menjadi bukti bahwa lulusan yang belajar dengan sunggu-sungguh di pesantren Bayt Tamyiz berani menciptakan prestasi yang positif untuk dirinya dan pesantren pada khususnya.

Penilaian karakteristik santri pesantren Bayt Tamyiz diantaranya adalah turunan penilaian dari penilaian motivasi dan kebiasaan belajar santri. Apabila santri dalam kebiasaan belajarnya malas, maka penilaian karakteristik santri juga tidak baik atau dalam kategori $\mathrm{C}$.

Seluruh penilaian yang dilaksanakan memiliki pengaruh santri, apakah ia layak dinaik tingkatkan atau mengulangi pembelajaran dengan pendalaman materi yang sama.

Menurut peneliti, penilaian yang diterapkan pesantren ini sangatlah detail. Hal tersebut dapat dilihat dari beberapa assessment (alat) untuk mengukur kemampuan, motivasi dan lain sebagainya santri selama belajar. Bahkan tingkah laku juga tidak luput menjadi perhatian pesantren. Akhlakul Karimah merupakan tujuan pesantren ini didirikan. Menurut abah, akhlakul karimah diibaratkan sebagai baju yang dikenakan oleh seseorang. Jika baju yang dikenakan layak dan baik, maka orang yang mengenakannya juga akan terlihat baik. begitu pula dengan akhlak, jika seseorang memiliki akhlak yang baik, maka orang tersebut akan terlihat baik di mata orang lain dengan akhlaknya begitupun sebaliknya.

\section{Konsep Model Pembelajaran Kitab kuning Pola 100 Jam Menggunakan Metode Tamyiz di Pesantren Bayt Tamyiz Tukdana Indramayu}

Penerapan model konsep pembelajaran kitab kuning pola 100 jam pesantren Bayt Tamyiz Desa Sukaperna Kecamatan Tukdana Kabupaten Indramayu dapat dikatakan sebagai salah satu sistem pendidikan di pesantren yang menggunakan metode pembelajaran yang baru karena pembelajaran kitab kuning yang dilakukan hanya membutuhkan waktu selama 100 jam setara dengan empat pekan santri yang belajar sudah mampu membaca, menerjemahkan, dan menulis (imla). Selain itu, pondok pesantren ini juga dalam melakukan perencanaan pembelajarannya dinilai tepat karena keterpaduan riset yang dilakukan oleh pengasuhnya diintegrasikan dengan hasil penelitian ilmuan dalam merencakan pembelajaran. Selain itu, usaha yang dilakukan sebagai bentuk pengalaman (by experience) baik seluruh steakholder yang terlibat dalam pembelajaran kitab kuning ini agar bertindak sesuai dengan mekanisme, alur, dan aturan yang telah disepakati, bukan berdasarkan keinginan hati belaka maupun egosentris.

Pelaksanaan pembelajaran kitab kuning pola 100 jam tidak dianggap sebagai sebuah kekakuan, melainkan disesuaikan dengan kemampuan santri, kondisi belajar dan gaya belajarnya. Cara-cara yang dilakukan pengajar dalam mengajarkan metode Tamyiz dipandang efektif, sehingga santri secara bertahap memiliki kemampuan menerjemahkanQuran dan kitab kuning, membaca Quran dan kitab kuning, menulis (imla) Quran dan kitab kuning hingga cakap menggunakan kitab kuning digital seperti maktabah syamilah, kitab as-Sab'ah, dan lain sebagainya dan diharapkan kemampuan-kemampuan tersebut dapat dirasakan oleh seluruh santri yang belajar.

Konsep model adalah pembahasan peneliti dalam mengungkapkan penerapan metode Tamyiz menjadi metode yang mudah difahami dan ditempuh dalam jangka waktu yang relatif pendek. Penerapan pembelajaran metode tamyiz hanya cukup dalam waktu empat pekan sama halnya jika dalam hitungan hari adalah satu bulan (empat pekan). Hal tersebut dianggap cepat karena pada umumnya pesantren yang mengajarkan santrinya pembelajaran kitab kuning minimal dalam jangka waktu yang panjang yaitu belajar selama empat tahun dan hasil yang dirasakan pun kurang terfokus. Berbeda halnya dengan pembelajaran kitab kuning pola 100 jam menggunakan metode Tamyiz yang cukup ditempuh 100 jam sama halnya kita belajar kitab kuning di pesantren selama 4 tahun. 
Metode Tamyiz merupakan metode mengajarkan yang baru dan mudah difahami oleh santri. Alasan tersebut membuat beberapa utusan pesantren, sekolah bahkan perguruan tinggi melakukan studi banding dan penelitian metode Tamyiz. Banyaknya penelitian yang dilaksanakan, maka banyak pula orang yang penasaran dengan konsep pembelajaran yang sesungguhnya sehingga peneliti perlu membahas pula model konsep apakah yang diterapkan dalam metode ini dengan beberapa rumpun pendalaman teori, diantaranya adalah mengetahui tentang kepemilikan nama, landasan filosofis pembelajaran, landasan teori pembelajaran, langkah dan teori yang diterapkan, dan komponenkomponen lainnya.

Landasan filosofis ringan abah mengenai konsep pembelajaran kitab kuning adalah ketika abah berziaroh ke maqom Imam Syafi'i. Abah memikirkan kehebatan intellegency Imam Syafi'i yang mampu menguasai Quran dan kitab kuning diusia remaja. Selain itu, abah mencoba menformulasikan teori dasar Quantum nahwu dan shorof merupakan kategori tujuan yang spesifik (Arabic Spesific Pupose) dengan target adalah sejak kecil (SD/MI) santri mampu membaca, menerjemahkan, dan menulis (imla) Quran dan kitab kuning.

Kepemilikan nama Tamyiz awalnya adalah berasal dari seorang tokoh kyai yang mengajarkan Quran dan kitab kuning di Desa Sukaperna Kecamatan Tukdana Kabupaten Indramayu yaitu Kyai Tamyiz pada tahun 1905. Hingga saat ini, nama Tamyiz menjadi metode cara santri mudah menerjemahkan, menulis dan memahami Quran dan kitab kuning.

Langkah-langkah pembelajaran dan pola kegiatan pembelajarannya menjadi salah satu konsep pembelajaran kitab kuning pola 100 jam menggunakan metode tamyiz. Langkah pembelajaran metode Tamyiz diantaranya adalah santri harus mampu membaca Quran. Hal tersebut merupakan syarat utama santri sebelum menempuh tingkatan tamyiz selanjutnya. Kemudian, santri harus mengikuti materi hingga handbook Tamyiz 2, yaitu memahami materi nahwu shorof dan pengaplikasiannya dalam Quran dan kitab kuning. Dalam risetnya, abah menjelaskan bahwa terdapat beberapa pengulangan yang terjadi di Quran. Terdapat pengulangan mufrodat 540 mufrodat yang paling sering diulang, diantaranya adalah 185 huruf diulang sebanyak 26.786 kali, 105 isim diulang sebanyak 10.477 kali, 140 fíl sering diulang sebanyak 12.773 kali, dan 140 isim dan fiil yang terjemahannya sama dalam bahasa Indonesia diulang sebanyak 10.096 kali dalam Quran. Jadi dari pembahasan tersebut, peneliti menyimpulkan bahwa belajar nahwu shorof merupakan pembelajaran yang mudah karena dalam Quran juga mengalami beberapa kali pengulangan.

Pengajar dalam memberikan pengalaman dan bahan ajarnya harus secara menyeluruh merupakan prioritas yang harus diperhatikan oleh para pengajar dan seluruh santri dalam setiap pertemuan. Hal tersebut menjadikan rangsangan tersendiri kepada santri agar tidak tertinggal di salah satu materi yang diperdalam serta mendorong santri-santri agar berlomba-lomba dalam kebaikan (فانتبقو الخيرت). Serta mendorong santri agar supaya menjadikan agamanya sehari-hari, kemudian menjadikan agama sebagai landasan akhlak, membangun spiritual mental santri untuk bersikap jujur, amanah, kerja keras, mandiri, percaya diri, kompetitif, kooperatif, accountable dan mampu menjadi guru yang mengajarkan metode Tamyiz di lingkungan mereka masing-masing.

Pada konsep model manajemen pembelajaran kitab kuning pola 100 jam menggunakan metode Tamyiz sudah cukup baik. Salah satunya adalah tepatnya nama yang digunakan. Tamyiz merupakan nama salah satu tokoh yang mengajarkan Quran dan kitab kuning sehingga pembelajaran yang dilakukan pondok pesantren dapat berlangsung hingga sekarang. Namun dalam komponen-komponen pendidikan seperti guru, hal tersebut memang disadari oleh abah bahwa masih lemahnya dalam menerapkan manajemen dan standardisasi rekruitmen pengajar yang baru. 
Menurut peneliti untuk mengetahui model konsep yang diterapkan metode pembelajaran ini adalah dengan rasa keingintahuan yang tinggi. Hal itu menjadikan seseorang tidak merasa puas dengan hal atau informasi yang ia dapatkan hingga data yang didapatkan terjamin validitasnya. Agar memudahkan pembaca, konsep model pembelajaran kitab kuning pola 100 jam menggunakan metode Tamyiz seperti gambar di bawah ini :

Gambar 1. Konsep Model Pembelajaran Kitab Kuning Pola 100 Jam Menggunakan Metode Tamyiz

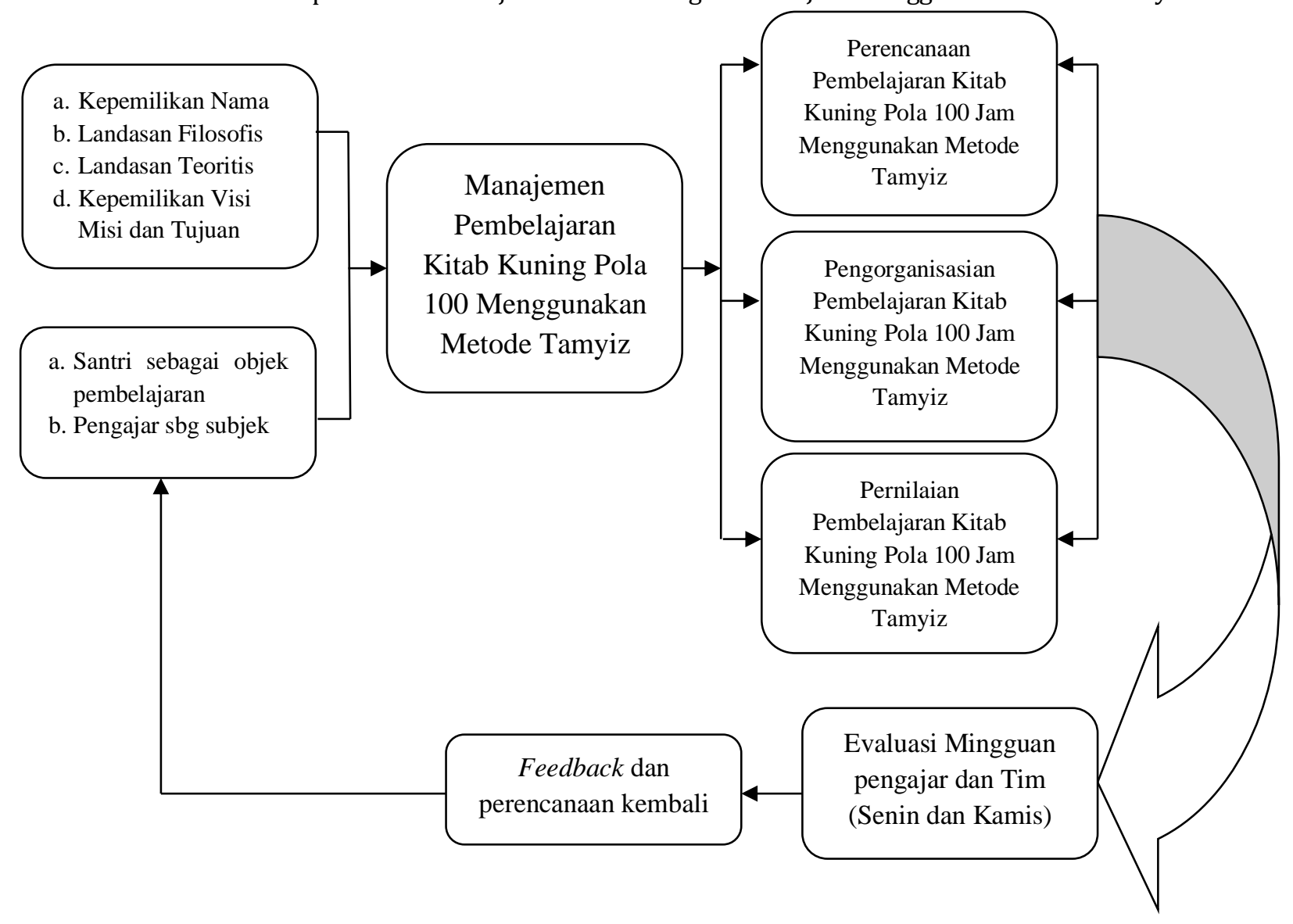

Interpretasi, Pondok pesantren melakukan perannya sebagai fungsi penyeimbang kebutuhan manusia agar supaya memiliki akhlakul karimah dan pengetahuan keagaamn yang baik, hal tersebut diharapkan dapat diterapkan dalam sistem pondok pesantren secara menyeluruh sehingga tercapai pula tujuan pendidikan pada umumnya yang bercita-cita menciptakan generasi yang bertakwa kepada Tuhan Yang Maha Esa, dan lain sebagainya. Maka, dalam penerapannya, pondok pesantren dibantu dengan fungsi-fungsi manajemen pada setiap kegiatan dan sistem yang direncanakan, dilakukan dan dievaluasi. Selain itu, dengan menggunakan fungsi manajemen tersebut diharapkan kegiatan pembelajaran keagamaan yang dilakukan pondok pesantren dapat terlaksana sesuai dengan yang diharapkan.

Namun pada interpretasi, peneliti membatasi pembahasan sesuai dengan kebutuhan yaitu perencanaan, pelaksanaan dan penilaian pembelajaran kitab kuning pola 100 jam menggunakan metode Tamyiz yang diterapkan pada pondok pesantren Bayt Tamyiz Tukdana Indramayu. Langkah-langkah dilakukan agar supaya dapat mengefektifitaskan seluruh program sehingga dapat mencapai tujuan yang diharapkan, adanya perencanaan pembelajaran kitab kuning dapat menggambarkan bahwa kegiatan 
pembelajaran yang dilakukan dalam metode Tamyiz bukan muncul atau terjadi secara insidental (tibatiba), asal-asalan dan tanpa arah, melainkan telah dirancang sedemikian rupa oleh tim dan pengasuh pondok peantren Bayt Tamyiz sedemikian rupa (by design) ehingga memiliki tujuan dan alur yang jelas serta accountable (dapat dipertanggungjawabkan) baik secara hukum, paedagogis, maupun secara sosial.

Perencanan pembelajaran kitab kuning pola 100 jam menggunakan metode Tamyiz ini dilakukan di Pondok Pesantren Bayt Tamyiz merupakan langkah-langkah yang tepat untuk menjadikan khazanah keilmuan dan pendidikan keagamaan lebih profesional serta menghasilkan lulusan (output) dan bahkan outcome yang beriman bertakwa, dan ber-akhlakul karimah sesuai dengan tujuan pendidikan tersebut. Adapun hal-hal yang dilakukan pada setiap aspek merupakan upaya nyata pondok pesantren agar pelaksanaan kegiatan pembelajaran kitab kuning pola 100 jam ini mengacu pada kaidah-kaidah yang sesuai dengan peranan keilmuan yang baik dan benar.

Selain itu, usaha yang dilakukan sebagai bentuk pengalaman (by experience) baik seluruh steakholder yang terlibat dalam pembelajaran kitab kuning ini agar bertindak sesuai dengan mekanisme, alur, dan aturan yang telah disepakati, bukan berdasarkan keinginan hati belaka maupun egosentris.

Pembinaan akhlak santri di pondok pesantren Bayt Tamyiz selama berasrama dilakukan dengan cara-cara yang sederhana, mudah dan menyenangkan tetapi penuh makna (menaingfull). Pondok pesantren ini tidak membatasi ataupun melebih-lebihkan ke-ta'dzim-an terhadap asatidz maupun abah karena hal tersbut dapat menjadi batasan pemahaman dan kesenjangan terhadap santri apabila ingin bertanya sesuatu hal yang ia belum fahami. Metode pembinaan akhlak di pondok pesantren Bayt Tamyiz ini dengan membiasakan saling menghargai sesama santri dan asatidz, berjabat tangan,senyum, dan menjadi mentor teman sebaya karena hal tersebut mampu meleburkan kecanggungan santri selama belajar. Cara mengajar yang dilakukan juga menggunakan prinsip Neuro Linguistic, guru akan mengajar dengan fun and active teaching. Jadi, secara tersirat guru mengajarkan saling meghargai kepada santri/ murid.Peneliti memandang bahwa cara-cara seperti demikian itu sangat baik dan bisa diikuti oleh pondok pesantren lainnya.

Pengalaman dan memberikan materi dan bahan ajar secara menyeluruh menjadikan prioritas yang harus diperhatikan oleh para pengajar dan seluruh santri dalam setiap pertemuan.Hal tersebut menjadikan rangsangan tersendiri kepada santri agar tidak tertinggal di salah satu materi yang diperdalam serta mendorong santri-santri agar berlomba-lomba dalam kebaikan (فاستقوا الخيرت). Serta mendorong santri agar supaya menjadiakn agamanya sehari-hari, kemudian menjadikan agama sebagai landasan akhlak, membangu spiritual mental santri untuk bersikap jujur, amanah, kerja keras, mandiri, percaya diri, kompetetif, kooperatif, accountable, dan mampu menjadi guru yang mengajarkan metode Tamyiz ini di lingkungan mereka masing-masing.

Untuk memperbaiki manajemen pembelajaran kitab kuning pola 100 jam menggunakan metode Tamyiz yang dirasakan masih belum cukup, pondok pesantren telah melakukan upaya yang tepat. Tepat dalam hal waktu (dilakukan secara terstruktur), dan tepat dalam hal kerjasamanya dengan berbagai pihak yang memiliki asas kemanfaatan untuk menjadi mitra pendidikan seperti orang tua, pemerintah daerah, masyarakat sekitar, alumni, asatidz, dan lain sebagainya.

\section{SIMPULAN}

Perencanaan pembelajaran kitab kuning pola 100 jam menggunakan metode Tamyiz di pondok pesantren Bayt Tamyiz Tukdana Indramayu dilaksanakan dengan tahap mengidentifikasi tujuan pembelajaran terlebih dahulu sebelum melakukan perencanaan pembelajaran. Setelah mengidentifikasi tujuan pembelajaran, selanjutnya mengembangkan materi pembelajaran, kegiatan pembelajaran, 
merencanakan metode pembelajaran, mengidentifikasi media pembelajaran yang dibutuhkan, merencanakan sumber pembelajaran, merencanakan evaluasi pembelajaran sesuai dengan kebutuhan ketercapaiannya tujuan pembelajaran. Perencanaan selanjutnya yang dilakukan oleh pengajar adalah mengembangkan materi yang sudah disiapkan sebelumnya dalam handbook Tamyiz. Keseluruhan komponen perencanaan tersebut dilakukan agar dapat meminimalisir kesalahan-kesalahan yang terjadi ketika pengorganisasian. Perencanaan yang dilaksanakan sudah dikembangkan dengan baik.Pengorganisasian pembelajaran kitab kuning tersebut harus tetap konsisten karena ada beberapa aspek yang harus diperlukan perhatian. Pengorganisasian pembelajaran kitab kuning pola 100 jam menggunakan metode Tamyiz di pondok pesantren Bayt Tamyiz Tukdana Indramayu menggunakan riset dan buku (handbook) yang telah dirancang oleh abah dan seluruh tim pengajar serta bidang pendidikan dan pengajaran. Buku yang digunakan santri pada umumnya adalah buku yang akan mereka gunakan selama pembelajaran berlangsung. Buku pegangan santri dalam pembelajaran Tamyiz ini terdiri dari beberapa jilid. Pertama, Tamyiz 1. Buku Tamyiz satu di dalamnya adalah mengenal huruf. Kedua, buku handbook Tamyiz 2. Buku Tamyiz dua di dalamnya berisikan tentang syair-syair dan kaidah nahwu-shorof yang harus santri kuasai. Pendekatan yang dilakukan selama pengorgansiasian, pengajar memiliki prinsip yang harus dilaksanakan, yaitu menyampaikan materi sesuai dengan kondisi santri, tidak mengandung kekerasan atau hal yang membuat santri tidak nyaman dalam belajar. Prinsip tersebut disebut dengan prinsip Fun and Active teaching (mengajar dengan aktif dan menyenangkan). Penilaian pembelajaran kitab kuning pola 100 jam menggunakan metode tamyiz di pondok pesantren Bayt Tamyiz Tukdana Indramayu yang diselenggarakan pada pesantren Bayt Tamyiz berbeda dengan pesantren lain pada umumnya. Pada pesantren Bayt Tamyiz, santri menjadi objek yang benar-benar diperhatikan. Penggunaan assasment (alat) untuk mengukur kemampuan santri juga digunakan agar supaya santri yang melanjutkan program selanjutnya benar-benar santri yang mampu bukan dari segi materi pembelajaran saja melainkan dari karakter kepribadian, emosi dan lain sebagainya. Hal tersebut dilakukan agar santri mampu bertanggungjawab atas dirinya dan terciptanya sikap disiplin dalam diri santri. Metode evaluasi yang sering digunakan oleh pengajar metode tamyiz adalah metode drill, yaitu bertanya secara spontan kepada santri dan mereka berusaha menjawabnya. Selain itu, penilaian pembelajaran yang sangat berpengaruh terhadap naiknya tingkatan teori belajar mereka adalah penilaian sumatif dan formatif. Karakteristik santri juga menjadi salah satu bahan penilaian pengajar. Hal tersebut agar lulusan pesantren Bayt Tamyiz selain mampu menerjemah, membaca, menulis (imla) dan memahami Quran dan kitab kuning, mereka pun memiliki akhlakul karimah. Konsep model pembelajaran kitab kuning pola 100 jam menggunakan metode Tamyiz (metode cepat menerjemahkan Quran dan menguasai kitab kuning) yang mudah difahami dan ditempuh dalam jangka waktu yang relatif pendek. Konsep kepemilikan nama, pengembangan landasaran filosofis metode Tamyiz, keikutsertaan komponen-komponen pendidikan seperti guru, dan pelajar. Kepemilikan nama metode pembelajaran Tamyiz sebenarnya berasal dari salah satu tokoh Kyai yang mengajarkan Quran dan kitab kuning di Desa Sukaperna, yaitu Kyai Tamyiz. Hal tersebut dilanjutkan oleh generasi Kyai (putra-putrinya) dan mendirikan beberapa pendidikan formal dan non-formal. Kepemilikan nama menjadi sah sebagai metode Tamyiz di Pondok Pesantren sejak terbitnya badan hukum Yayasan at-Tamyizy. Landasan filosofis ringan abah mengenai konsep pembelajaran kitab kuning adalah ketika abah berziaroh ke maqom Imam Syafi'i. Abah memikirkan kehebatan intellegency Imam Syafi'i yang mampu menguasai Quran dan kitab kuning diusia remaja. Selain itu, abah mencoba menformulasikan teori dasar Quantum nahwu dan shorof merupakan kategori tujuan yang spesifik (Arabic Spesific Pupose) dengan target adalah sejak kecil (SD/MI) santri mampu membaca, menerjemah, dan menulis (imla) Quran dan kitab kuning. 


\section{DAFTAR PUSTAKA}

Al-Tabany, T. I. B. (2014). Mendesain Model Pembelajaran Inovatif, Prograsif, Dan Kontekstual. Jakarta: Prenadamedia Group.

Badrudin. (2014). Manajemen Peserta Didik. Jakarta: Indeks.

Buckley Philip Dan Irawan. (2015). The Scientific Paradigm Of Islamic Education Management: Phenomenology Perspective. Jurnal Pendidikan Islam, 2(1).

Cresswell John W. (2014). Research Design; Pendekatan Kualitatif, Kuantitatif, Dan Mixed. Yogyakarta: Pustaka Pelajar.

Dhofier, Z. (2015). Tradisi Pesantren. Jakarta: Lp3es.

Irawan. (2019). Filsafat Manajemen Pendidikan Islam. Bandung: Rosdakarya.

Iryana, W. (2014). Baban Kana. Bandung: Pustaka Aura Semesta.

Komariah, Y. S. M. Dan A. (2014). Manajemen Pendidikan. Bandung: Alfabeta.

Mu'ammar, M. N. (2019). Study Of Approaches, Methods, Sources And Interpretation Instruments Of Mulla Sadra. International Journal Of Islamic Khazanah, 9(1), 1-8.

Muchit, S. (2013). Pembelajaran Kontekstual. Semarang: Rasail Media Grup.

Muhammad Alfan Alfian. (2019). Politik Zonasi Dalam Praktik Pendidikan Di Indonesia. Politicon: Jurnal Ilmu Politik, 2(1), 117-133.

Qomar, M. (2013). Pesantren Dari Transformasi Metodologi Menuju Demokratisasi Institusi. Jakarta: Erlangga.

Rayana, J. (2019). Hadits Information About Helping (Completing) With Something Happened In The Society. International Journal Of Islamic Khazanah, 9(1), 35-40.

Silalahi, U. (2014). Asas-Asas Manajemen. Bandung: Refika Aditama.

Sugiyono. (2013). Metode Penelitian Pendidikan Pendekatan Kauntitatif, Kualitatif Dan R\&D. Bandung: Alfabeta.

Terry, G. (2014). Prinsip-Prinsip Manajemen. Jakarta: Bumi Aksara.

Ujiyati, S. Dan T. (2013). Manajemen Dalam Pembelajaran. Jakarta: Indeks.

Yaumi, M. (2013). Prinsip-Prinsip Pembelajaran. Jakarta: Kencana. 